\title{
STUDI NUMERIK POLA GESER BLOK ALTERNATIF PADA SAMBUNGAN UJUNG BATANG TARIK PROFIL T
}

\author{
Hendy Wijaya ${ }^{1}$ \\ ${ }^{1}$ Jurusan Teknik Sipil, Universitas Tarumanagara Jakarta \\ rm.hendy@yahoo.com
}

\begin{abstract}
ABSTRAK
Geser blok merupakan salah satu kriteria yang harus dipenuhi dalam mendesain sambungan batang tarik pada komponen struktur baja. Hasil studi eksperimental yang dilakukan pada profil T yang disambung pada bagian sayap dengan alat penyambung baut memperlihatkan pola kegagalan geser blok yang diistilahkan dengan alternate path block shear (ABS) failure. Pola kegagalan ini masih belum diperhitungkan dalam peraturan baja terkini. Studi numerik telah dilakukan pada beberapa profil T yang ada di pasaran Indonesia dengan konfigurasi baut tertentu. Distribusi tegangan pun menunjukkan indikasi yang menyerupai kegagalan ABS tersebut. Makalah ini memaparkan hasil studi numerik dengan metode elemen hingga mengenai pengaruh dari mutu baja terhadap indikasi kegagalan ABS pada beberapa profil T. Mutu baja BJ 34, BJ 37, BJ 50, dan BJ 55 ditinjau pada studi ini. Dari 20 model yang dianalisis, seluruhnya memperlihatkan deformasi dan distribusi tegangan yang menyerupai kegagalan ABS. Hal ini menandakan bahwa adanya indikasi terhadap kegagalan ABS pada batang tarik profil T yang disambung dengan alat penyambung baut pada bagian sayap untuk semua jenis mutu baja di Indonesia.
\end{abstract}

Kata kunci: geser blok, profil T, alternate path block shear failure

\section{PENDAHULUAN}

Geser blok merupakan salah satu kriteria yang harus dipenuhi dalam mendesain sambungan batang tarik pada komponen struktur baja. Ragam kegagalan ini terjadi apabila material gagal akibat tegangan tarik disertai tegangan geser pada segmen yang saling tegak lurus. Pada profil T yang disambung pada bagian sayap dengan alat penyambung baut, kegagalan geser blok yang diharapkan terjadi diilustrasikan pada Gambar 1.

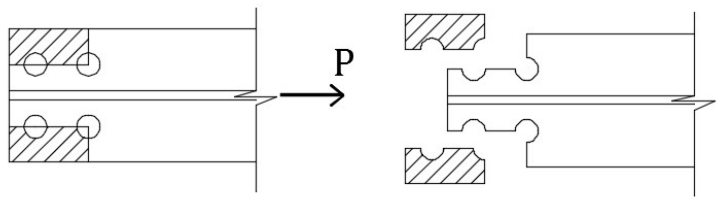

Gambar 1. Kegagalan geser blok yang diharapkan terjadi

Jenis sambungan satu sisi demikian menyebabkan timbulnya eksentrisitas antara sambungan dengan titik berat dari penampang. Studi menunjukkan bahwa adanya eksentrisitas pada sambungan batang tarik menginduksi deformasi lentur yang dapat mengurangi kapasitas dari komponen struktur tersebut (Geethu, C.V, et al., 2014).

SNI (2015) mengasumsikan bahwa kegagalan geser blok terjadi akibat putus sepanjang bidang geser dan putus sepanjang bidang tarik. Masing-masing bidang menyumbangkan kekuatan, dan kekuatan geser blok merupakan penjumlahan dari kekuatan yang disumbangkan oleh masingmasing bidang tersebut. Persamaan kekuatan geser blok yang digunakan:

$\phi R_{n}=\phi\left(0,60 F_{u} A_{n v}+U_{b s} F_{u} A_{n t}\right) \leq \phi\left(0,60 F_{y} A_{g v}+U_{b s} F_{u} A_{n t}\right)$

dengan $\psi=$ faktor ketahanan, $F_{\mathrm{v}}=$ kekuatan tarik minimum yang dispesifikasikan, $F_{y}=$ tegangan leleh minimum yang dispesifikasikan, $A_{g v}=$ luas bruto bidang geser pada geser blok, $A_{n v}=$ luas neto bidang geser pada geser blok, $A_{m t}=$ luas neto bidang tarik pada geser blok, $U_{\eta_{m}}=$ faktor reduksi geser blok. 
Studi eksperimental yang dilakukan terhadap jenis sambungan ini menunjukkan pola kegagalan geser blok yang berbeda, yang diistilahkan dengan alternate path block shear (ABS) failure (Epstein, 1996; Epstein dan Stamberg, 2002). Pola ini melibatkan tegangan tarik pada penampang melintang dari sayap dan tegangan geser pada penampang memanjang dari badan profil. Gambar 2 menunjukkan salah satu spesimen yang mengalami ABS.

Hasil studi numerik yang dilakukan terhadap 5 profil $\mathrm{T}$ dengan jenis mutu baja BJ 41 pada konfigurasi sambungan tertentu juga mengindikasikan terjadinya ABS (Wijaya dan Suryoatmono, 2017). Gambar 3 memperlihatkan distribusi tegangan yang dialami oleh salah satu profil yang diuji.

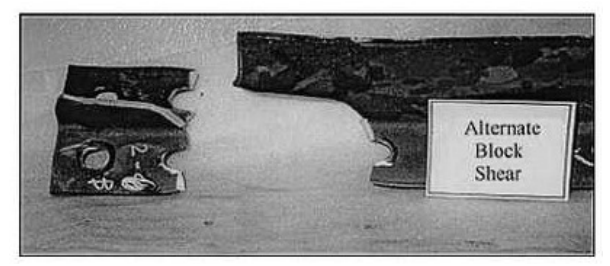

Gambar 2. Spesimen yang mengalami kegagalan ABS (Epstein, 1996)

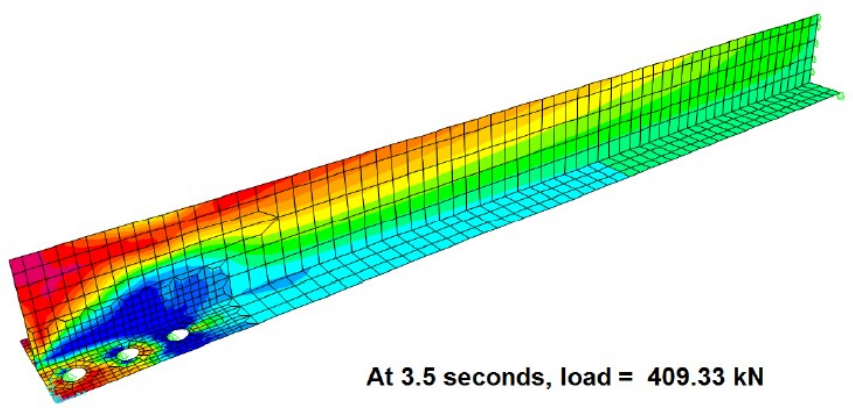

Gambar 3. Distribusi tegangan yang mengindikasikan ABS (Wijaya dan Suryoatmono, 2017)

Desain komponen struktur baja tidak terlepas dari pengaruh jenis mutu baja yang digunakan. Perubahan jenis mutu baja berarti merubah sifat mekanis dari baja itu sendiri sehingga akan mempengaruhi hasil dari desain komponen struktur tersebut. Sifat mekanis baja struktural yang digunakan dalam perencanaan diberikan pada Tabel 1.

Makalah ini memaparkan hasil studi numerik yang dilakukan dengan bantuan perangkat lunak berbasis elemen hingga dalam mempelajari pengaruh dari jenis mutu baja terhadap indikasi kegagalan ABS pada beberapa profil $T$ yang disambung pada bagian sayap dengan alat penyambung baut. Studi ini merupakan lanjutan dari studi yang telah dilakukan oleh Wijaya dan Suryoatmono (2017).

\section{METODE PENELITIAN}

Studi ini menganalisis beberapa profil hot-rolled berpenampang $\mathrm{T}$ yang ada di pasaran Indonesia dengan berbagai jenis mutu baja. Analisis dilakukan dengan menggunakan metode elemen hingga (MEH). 
Tabel 1. Sifat mekanis baja struktural (SNI, 2002)

\begin{tabular}{lccc}
\hline $\begin{array}{l}\text { Jenis } \\
\text { Baja }\end{array}$ & $\begin{array}{c}F_{u} \\
(\mathrm{MPa})\end{array}$ & $\begin{array}{c}F_{y} \\
(\mathbf{M P a})\end{array}$ & $\begin{array}{c}\text { Regangan } \\
\text { minimum } \\
(\%)\end{array}$ \\
\hline BJ 34 & 340 & 210 & 22 \\
\hline BJ 37 & 370 & 240 & 20 \\
\hline BJ 41 & 410 & 250 & 18 \\
\hline BJ 50 & 500 & 290 & 16 \\
\hline BJ 55 & 550 & 410 & 13 \\
\hline
\end{tabular}

\section{Penentuan benda uji}

Dimensi profil dan konfigurasi sambungan yang akan dianalisis mengacu pada 5 benda uji yang digunakan oleh Wijaya dan Suryoatmono (2017). Tabel 2 menunjukkan dimensi profil dan konfigurasi sambungan yang dimaksud. Tipikal geometri sambungan diperlihatkan pada Gambar 4.

Tabel 2. Dimensi profil dan konfigurasi sambungan

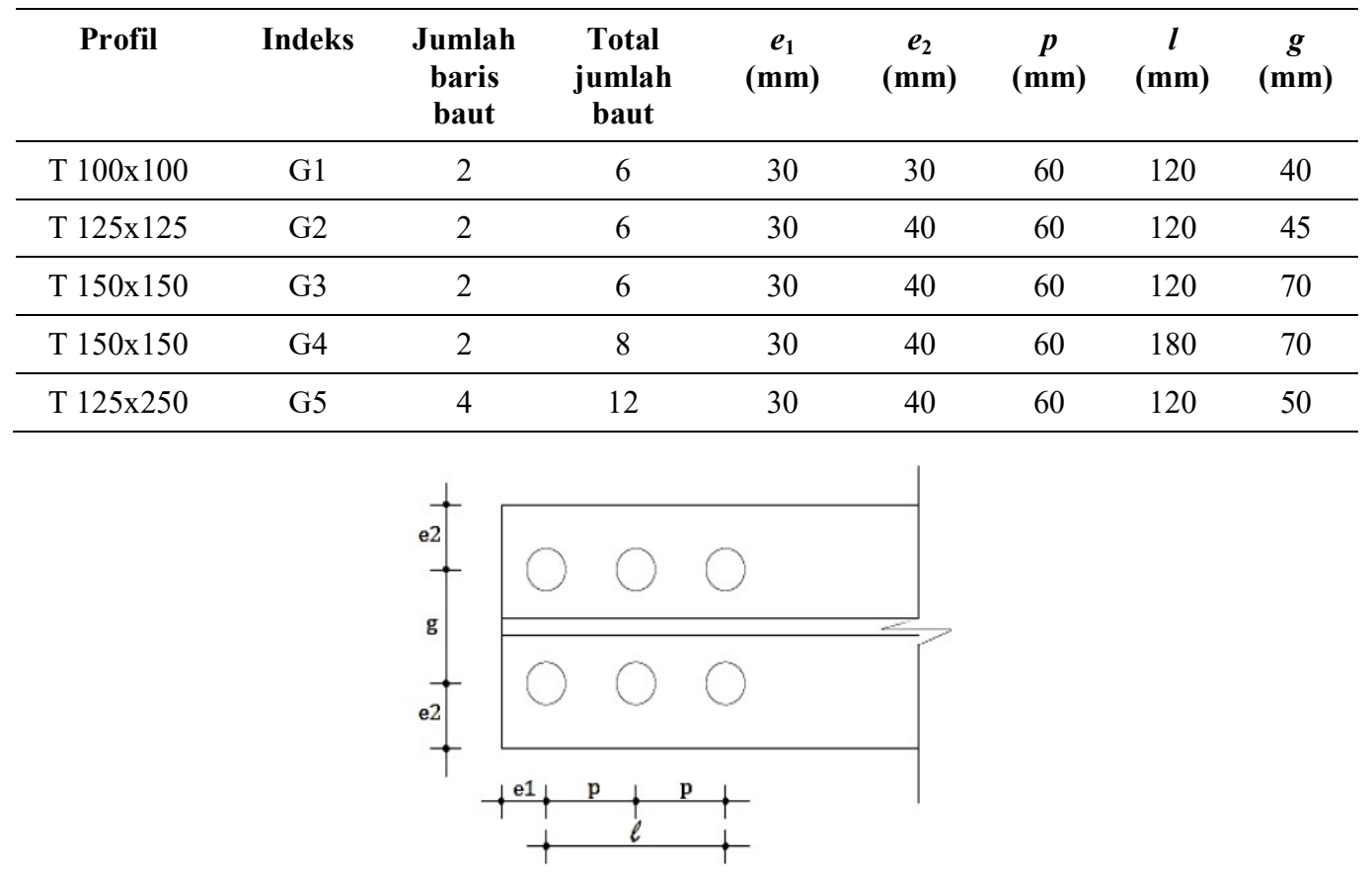

Gambar 4. Tipikal geometri dari sambungan (Wijaya dan Suryoatmono, 2017)

Dalam studi ini, kelima benda uji tersebut divariasikan pada jenis mutu baja, yakni BJ 34, BJ 37, BJ 50, dan BJ 55. Dua puluh benda uji diidentifikasi ragam kegagalannya dari hasil perhitungan menurut SNI (2005). Nilai $U_{b s}=1.0$ digunakan dalam perhitungan kekuatan geser blok. Ragam kegagalan ini kemudian dibandingkan dengan hasil MEH. 


\section{Model elemen hingga}

SAP2000 versi 15 digunakan dalam analisis 3D ini. Elemen yang digunakan dalam analisis adalah tipe elemen shell segiempat 4 nodal sebagai elemen utama, dipadukan dengan beberapa elemen shell segitiga 3 nodal sebagai elemen-elemen transisi. Sambungan dimodelkan pada salah satu ujung profil saja, dan ujung lainnya mencerminkan kondisi profil di luar daerah sambungan. Boundary conditions ditentukan sedemikian rupa sehingga analisis dapat mewakili kondisi sebenarnya. Baut diasumsikan rigid, sehingga dapat dianggap sebagai tumpuan. Kurang lebih separuh dari lubang baut ditahan terhadap translasi vertikal dan translasi horisontal. Sedangkan pada ujung yang jauh dari sambungan, setiap nodal ditahan terhadap translasi vertikal. Gambar 5 menunjukkan tipikal jaring elemen yang digunakan dalam analisis.

Pada studi ini, diperhitungkan pengaruh non-linieritas dari material dan non-linieritas dari geometri. Hubungan tegangan-regangan material diasumsikan elastic-perfectly plastic untuk semua jenis mutu baja tanpa memperhitungan tegangan sisa. Tipikal hubungan teganganregangan material ditampilkan pada Gambar 6. Non-linieritas dari geometri diperhitungan terhadap pengaruh P-Delta.

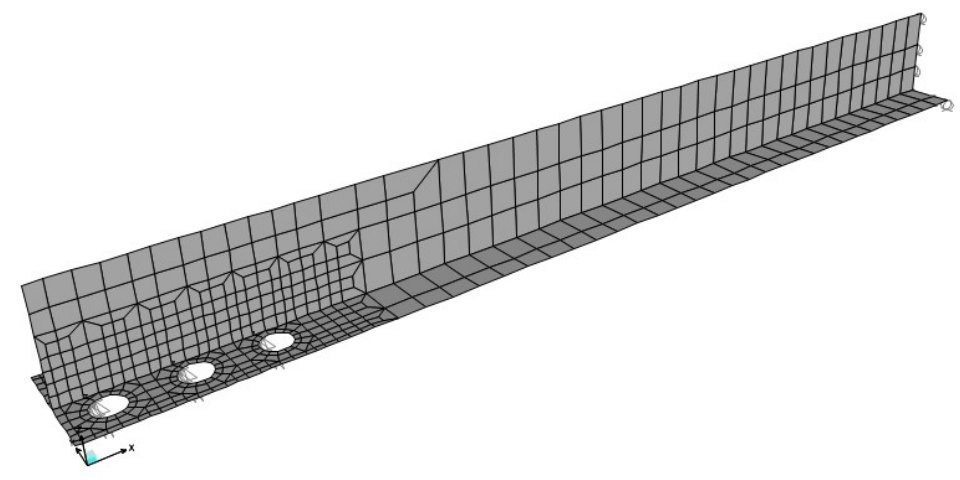

Gambar 5. Tipikal jaring elemen

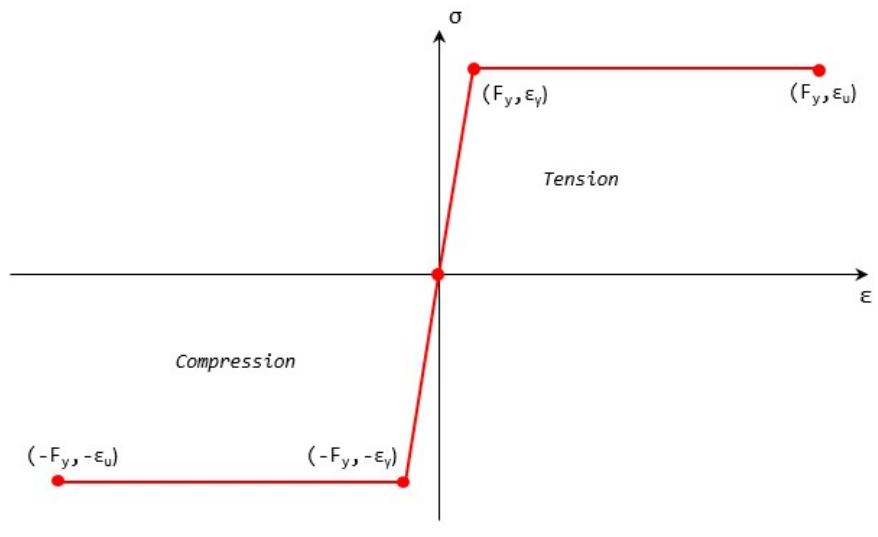

Gambar 6. Tipikal hubungan tegangan-regangan material

Pemberian beban berupa tegangan tarik diterapkan pada ujung yang jauh dari sambungan. Beban ditingkatkan nilainya secara linier terhadap waktu. Untuk menghindari adanya pengaruh gaya inersia yang dapat menyebabkan bergetarnya elemen, maka penambahan beban harus dilakukan secara sangat perlahan. Analisis beban riwayat waktu menggunakan metode integrasi langsung dengan formulasi Hilber, Hughes, dan Taylor (metode $\alpha$ ). Parameter $\alpha$ diambil sebesar $-0,3$. 
Untuk merekam respons perpindahan terhadap perubahan beban, digunakan metode NewtonRhapson dengan batas toleransi konvergensi gaya diambil sebesar 0,001. Analisis dihentikan ketika konvergensi sudah tidak tercapai lagi.

\section{HASIL DAN PEMBAHASAN}

Dalam analisis ini, retak tidak dimodelkan. Kegagalan geser blok atau putus pada penampang neto, keduanya merupakan peristiwa putus yang melibatkan proses terbentuknya retak dan penjalaran retak. Oleh sebab itu, ragam kegagalan hasil MEH tidak didefinisikan pada studi ini, melainkan dengan mempelajari dari deformasi dan proses penyebaran tegangan yang berlangsung sejak awal beban diberikan, maka indikasi terhadap salah satu ragam kegagalan dapat dilihat.

Dari 20 benda uji, seluruhnya memperlihatkan pola yang menyerupai kegagalan ABS. Gambar 7 memperlihatkan deformasi yang dialami salah satu benda uji. Dari gambar tersebut terlihat bahwa terjadi deformasi yang ekstrim pada kelompok baut terdepan dan pada pertemuan antara badan dengan sayap dari profil. Selain itu terlihat juga deformasi lentur yang dialami profil sebagai akibat dari eksentrisitas antara sambungan dengan titik berat penampang.

Distribusi tegangan yang dialami profil juga memperlihatkan indikasi yang serupa. Gambar 8 menunjukkan salah satu hasil distribusi tegangan yang terjadi pada benda uji G5 dengan jenis mutu baja BJ 50. Pada gambar terlihat bahwa tegangan terkonsentrasi di sepanjang alur kegagalan ABS, padahal secara perhitungan analitis benda uji ini mengalamai ragam kegagalan putus pada penampang neto (NS). Pada benda uji G4 dengan jenis mutu baja BJ 50, hasil perhitungan justru menghasilkan ragam kegagalan leleh pada penampang bruto (L). Hasil MEH menunjukkan bahwa konsentrasi tegangan lebih dulu terjadi pada alur ABS sebelum akhirnya penampang bruto mengalami pelelehan. Begitu juga dengan benda uji G3 dimana hasil perhitungan menyatakan ragam kegagalan geser blok (BS), akan tetapi MEH tidak memperlihatkan hal yang demikian. Ringkasan dari seluruh hasil analisis disajikan dalam Tabel 3.

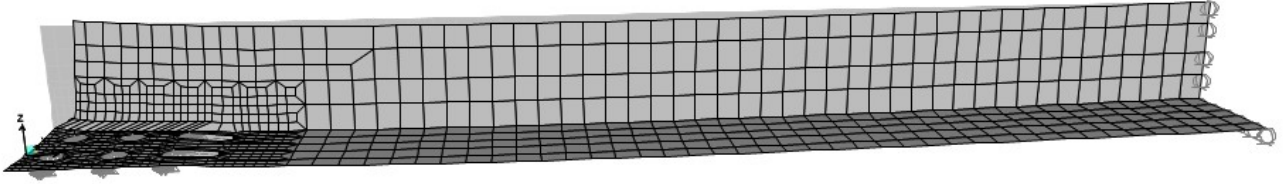

Gambar 7. Bentuk deformasi dari benda uji G5 BJ 50
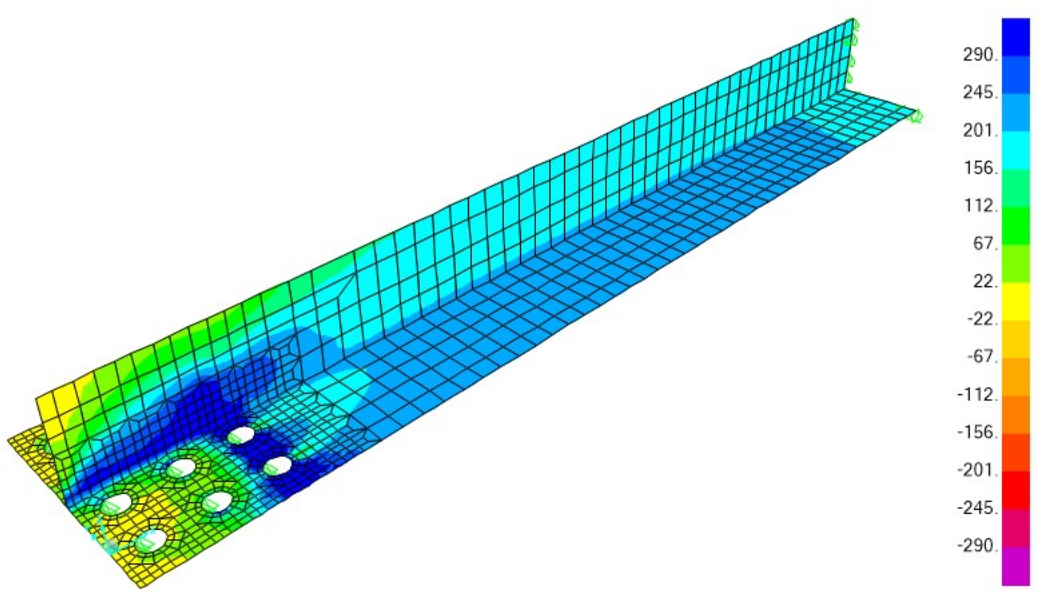

Gambar 8. Distribusi tegangan von-Mises pada benda uji G5 BJ 50 
Tabel 3. Perbadingan ragam kegagalan berdasarkan hasil perhitungan analitis dan MEH

\begin{tabular}{|c|c|c|c|c|c|c|c|}
\hline \multirow[t]{2}{*}{ No } & \multirow[t]{2}{*}{ Indeks } & \multirow{2}{*}{$\begin{array}{l}\text { Jenis } \\
\text { Baja }\end{array}$} & \multicolumn{3}{|c|}{ Perhitungan analitis (kN) } & \multicolumn{2}{|c|}{ Ragam kegagalan } \\
\hline & & & $\begin{array}{c}\text { Leleh } \\
\text { bruto } \\
\text { (L) }\end{array}$ & $\begin{array}{c}\text { Putus } \\
\text { neto (NS) }\end{array}$ & $\begin{array}{c}\text { Geser } \\
\text { blok } \\
\text { (BS) }\end{array}$ & Analitis & $\begin{array}{c}\text { Indikasi } \\
\text { FEM }\end{array}$ \\
\hline 1 & G1 & BJ 34 & 256,66 & 216,19 & 277,44 & NS & ABS \\
\hline 2 & G1 & BJ 37 & 293,33 & 235,26 & 301,92 & NS & ABS \\
\hline 3 & G1 & BJ 50 & 354,44 & 317,93 & 408,00 & NS & ABS \\
\hline 4 & G1 & BJ 55 & 501,10 & 349,72 & 448,80 & NS & ABS \\
\hline 5 & G2 & BJ 34 & 355,89 & 324,74 & 358,02 & NS & ABS \\
\hline 6 & G2 & BJ 37 & 406,73 & 353,40 & 389,61 & NS & ABS \\
\hline 7 & G2 & BJ 50 & 491,46 & 477,56 & 526,50 & NS & ABS \\
\hline 8 & $\mathrm{G} 2$ & BJ 55 & 694,83 & 525,32 & 579,15 & NS & ABS \\
\hline 9 & G3 & BJ 34 & 442,07 & 429,39 & 358,02 & BS & ABS \\
\hline 10 & G3 & BJ 37 & 505,22 & 467,28 & 389,61 & $\mathrm{BS}$ & $\mathrm{ABS}$ \\
\hline 11 & G3 & BJ 50 & 610,48 & 631,46 & 526,50 & BS & $\mathrm{ABS}$ \\
\hline 12 & G3 & BJ 55 & 863,09 & 694,61 & 579,15 & BS & ABS \\
\hline 13 & G4 & BJ 34 & 442,07 & 429,39 & 451,66 & NS & ABS \\
\hline 14 & G4 & BJ 37 & 505,22 & 467,28 & 491,51 & NS & ABS \\
\hline 15 & G4 & BJ 50 & 610,48 & 631,46 & 664,20 & $\mathrm{~L}$ & ABS \\
\hline 16 & G4 & BJ 55 & 863,09 & 694,61 & 730,62 & NS & ABS \\
\hline 17 & G5 & BJ 34 & 871,10 & 723,61 & 799,68 & NS & ABS \\
\hline 18 & G5 & BJ 37 & 995,54 & 787,46 & 870,24 & NS & ABS \\
\hline 19 & G5 & BJ 50 & 1202,95 & 1064,14 & 1176,00 & NS & ABS \\
\hline 20 & G5 & BJ 55 & 1700,72 & 1170,55 & 1293,60 & NS & ABS \\
\hline
\end{tabular}

\section{KESIMPULAN DAN SARAN}

Hasil studi ini memberi informasi bahwa adanya indikasi terhadap kegagalan ABS pada batang tarik profil $\mathrm{T}$ yang disambung dengan alat penyambung baut pada bagian sayap untuk semua jenis mutu baja di Indonesia.

Beberapa hal yang dapat dipertimbangkan untuk studi lebih lanjut antara lain dengan memodelkan retak dalam analisis, sehingga prediksi kekuatan dan ragam kegagalan dapat ditentukan secara lebih akurat, memperhitungkan adanya tegangan sisa pada material karena dalam kenyataaanya profil-profil hot rolled menderita tegangan sisa, memvariasikan konfigurasi sambungan yang digunakan atau bahkan bisa dengan melakukan uji eksperimental sehingga diperoleh lebih banyak data guna mendukung hasil studi ini. 


\section{Ucapan Terima Kasih}

Ucapan terima kasih disampaikan kepada Jurusan Teknik Sipil Universitas Tarumanagara yang telah memberi dukungan dengan menyediakan fasilitas perangkat lunak sehingga studi ini dapat berlangsung.

\section{REFERENSI}

Epstein, H. (1996). Block shear of structural tees in tension - Alternate paths. AISC Engineering Journal, Fourth Quarter, pp. 147-152.

Epstein, H. \& Stamberg, H. (2002). Block shear and net section capacities of structural tees in tension: Test results and code implications. AISC Engineering Journal, Fourth Quarter, pp. 228-239.

Geethu, C.V., Unni, K.G., Usha, S. (2014). Effect of connection eccentricity in the behavior of steel tension members. International Journal of Civil Engineering and Technology, Vol. 5, pp. 56-65.

SNI. (2002). Tata Cara Perencanaan Struktur Baja untuk Bangunan Gedung. SNI 03-1729-2002.

SNI. (2015). Spesifikasi untuk Bangunan Gedung Baja Struktural. SNI 1729-2015.

Wijaya, H. \& Suryoatmono, B. (2017). "Numerical study on alternate block shear failure mode of structural tee section loaded in tension". The $3^{\text {rd }}$ International SCESCM, Bali, September 5-7 2016, Vol. 171, pp. 865-873. 